\title{
Exemplified Values In Gunung Tidar At Magersari Village, Denoting The Northern Of Magelang, Magelang District Of Central Java (A Folklor Review)
}

\author{
Sundari \\ \{sundari@staff.uns.ac.id\} \\ Universitas Sebelas Maret
}

\begin{abstract}
The Gunung Tidar Folklore found in the Village of Magersari, District of North Magelang, District of Magelang, Central Java Province is very much related to the existence of folklore that developed in Java. The formulation of the problem taken is how the form and function of the Gunung Tidar Rayat Story in Magersari Village, Magelang District, Central Java Province and what Exemplary Values can be taken in the Gunung Tidar Folklore. The purpose of this research is to know the form and function of Gunung Tidar Folklore, and to know the exemplary values that can be taken from the Gunung Tidar Folklore. The research method used is descriptive qualitative research, using primary data sources and secondary data sources. Data collection techniques with interviews and data collection through books and other literature. Sheikh Subakir was sent to the Land of Java to spread Islamic teachings, after being on Mount Tidar Sheikh Subakir fought with the giant inhabitants of Mount Tidar (Kyai Semar) and finally won the battle. Until his lifetime Sheikh Subakir taught the teachings of Islam and finally was buried in Mount Tidar along with his weapon (Kyai Sepanjang). The form of this folklore is a legend because there is a human who became a character in the story. The function obtained is that he is considered to have supernatural powers so that many people who come with the aim of obtaining blessings so that their prayers are answered, the folklore of Mount Tidar is a form of cultural institutions that contain norms that are binding on society, if those norms violated the community will receive the consequences, the value of this education is implicit in the belief in the sacred place of Mount Tidar which is carried out with various ceremonies handed down to subsequent generations. Through trust in the figure of Sheikh Subakir, Kyai Semar, Kyai as long as they become a guide for them. The exemplary values obtained are Eitka Moral values, Cultural values, Religious values and the struggle value of Sheikh Subakir.
\end{abstract}

Keywords: folklore, Gunung Tidar, values, Magelang 


\section{Introduction}

Indonesia has many cultural heritages in the past which are the legacy of our diverse ancestors and many scientists are interested in doing research, one of which is folklore. Folklore is classified as a science or a cultural discipline, a broad science, anything can be included in it. The presence of folklore greatly enriched the cultural treasures concerned [1].

The spread of folklore in general through word or oral speech, folklore includes fairy tales, saga stories, heroism, customs, songs, ordinances, literature, arts and regional fashion. Folklore as a whole has the meaning of a nation's collective tradition which is spread by verbal forms and gestures, so that it continues to be sustainable from generation to generation. Folklore is a local identity found in traditional community life. a sense of belonging to deeply rooted and historic traditions causes people's emotions to become one. Although every day people are faced with news from all corners of the world, but still each lacks stories that deserve to be enjoyed. Indonesian people always need fiction or fairy tales all the time. Therefore, in reality many stories from the past such as legend (folklore) are believed to be still acceptable to the public [2].

According to Dundes, in his book Dr. Suwardi Endreaswara said etymologically, the word Folklor is the Indonesian of English word folklore. This word is a compound word, which comes from two basic words folk and lore. Folk is a group of people who have physical, social and cultural identification characteristics so that they can be distinguished from other groups. Their special characteristic is that they already have a tradition, which is a custom they have inherited from generation to generation, at least two generations that they can recognize as their common property [3].

Lore is a folk custom, which is part of its culture, which is passed down orally orally or through an example accompanied by gestures or reminders. Based on the understanding of folk and lore, it can be defined that folklore is a part of collective culture that is spread and passed down from generation to generation, traditionally in different versions, both in oral form and gesture or as a reminder aid [4].

According to Yadnya based on the type of culture, folklore is part of a culture that is traditional, informal, and national. This view implies that folklore is not only ethnic, but also national. The customs or culture of a group of people who possess physical and cultural identification characteristics can be interpreted that research on folklore in the archipelago is very broad and very diverse.

The definition of folklore based on the Big Indonesian Dictionary is story literature from ancient times that lived among the people and passed on orally. Folklore is a literary work that was born and developed in traditional society and distributed in a relatively fixed form, or in a standard form that is spread among certain collectives over a long time. One part of folklore is that folklore is a form of oral folklore that is passed down through word of mouth, because that is what spreads folklore experiences changes both in content and version adapted to the situations and conditions of the regions that receive the spread. Folklore can be interpreted as the cultural expression of a community through spoken language that is directly related to various aspects of culture such as religion and beliefs, family economic system laws and the social value structure of the community [5].

There are more categories than folklore. But basically, folklore can be divided into three major groups including: Myth, legend, and Tales (folktale): 1) Myth is a folk prose story that really happens and is considered sacred by the owner of the story. Mite ditokohi by gods or demigods, events occur in another world that we do not know now, and occurred in the past; 2) Legend is a folk prose that has characteristics similar to mite, which is considered to be 
true, but is not considered sacred, it is believed by humans, though at times with extraordinary qualities and often assisted by beings - supernatural beings; 3 ) Tales (folktale), in the form of folk prose stories that are not considered to actually occur by the owner of the story and fairy tales are not bound by time or place [6].

Folklore which is part of oral fochlor has a function according to Bascom ${ }^{9}$ folklore has four functions, namely: 1) as a projection system, namely as a means of reflecting the imagination of a collective. Folklore becomes a projection of people's dreams or as a means of satisfying or fulfilling people's dreams; 2) as an instrument of ratification of institutions and cultural institutions. Folklore often confirms existing institutions or institutions; 3) as an educational tool, folklore as an educational medium to deliver lessons to students in order to facilitate the teaching and learning process; 4) as a coercive and supervisory tool so that the norms in the community will always be obeyed by their collective members. Folklore contains "myths" that control humans to do or to forbid humans from doing anything [7].

Besides Dundes in his book Suwardi Endrawara ${ }^{10}$ added other functions, namely: 1) to strengthen the feeling of collective solidarity; 2) as a means of justifying a society; 3 ) provide direction to the community in order to denounce others; 4) as a means of protesting injustice; 5 ) as a fun and entertaining tool. All of these functions will be able to change people, especially young people, into a brighter future if used in the process of learning both in formal education, non-formal education, and informal education [8].

For example of Javanese folklore, will be a characteristic or Javanese identity that distinguishes it from other ethnic groups. Javanese identity will foster a collective spirit of Javanese. Javanese folklore is actually a product of the process of syncretizing various elements. Among them because of the influence of Hinduism, Buddhism and Islam. In Java, folklore still has values and norms, ethics, moral teachings that are still relevant today, their meaning and function are still very important especially for the collective owner. Studies on folklore can be used as a means of inculcating values and moral teaching in today's society, but it is also useful for literary works of the order itself [9].

On the island of Java, precisely in the District of Magelang, Central Java Province, there is an oral tradition of folklore scattered in various places. Gunung Tidar Folklore located in the village of Magersari, Magelang Regency, Central Java Province is known as the "Pakunya Tanah Jawa" which makes the land of Java remain calm and safe. At the top of Mount Tidar there is a field in the middle of the field that has a monument with the symbol "Sa" in Javanese letters on three sides and according to the caretaker there means "Sopo sing salah" or more or less means that whoever is guilty should admit his mistake. This legend is very attached to traditional Javanese society, not just in Magelang, but also to other areas in Java, even to foreign countries (Suriname).

In the past, the haunted of Tidar Mountain that circulated in the community was when someone came to the mountain if it didn't die, right? The origin of the name Tidar is a version that says that the name comes from the words "Mati dan Modar" it means dead. There are several versions of the Gunung Tidar Folk Story, the emergence of the Story of Sheikh Subakir who lives on Mount Tidar and defeated the jinn on Mount Tidar, making researchers interested in conducting research on the folklore [10].

Problems taken by the researcher are: 1) What is the form and function of Folklore entitled Gunung Tidar? 2) What is the exemplary values can be taken from Gunung Tidar Folklore? In the research of Gunung Tidar Folklore, the researchers wanted to provide the following objectives: 1) To know the form and function of Gunung Tidar Folklore; 2) To know the exemplary values that can be taken from Gunung Tidar Folklore. 


\section{Research Method}

This research uses descriptive qualitative research that is collecting data in the form of words in sentences or images that have meaning beyond numbers or frequencies. The analysis results obtained in this study are consistent with empirical data, namely how to describe each event that actually occurs. Data Source. There are two data sources used in this study, namely primary data sources and secondary data sources. The primary data sources in this study are people or informants and places or events. People who are thought to know the story of Mount Tidar are caretakers, traders, housewives, motorcycle taxi drivers and visitors who come to the location. The place of observation in this study is in Mount Tidar, Magersari Village, Magelang Regency, Central Java Province. Secondary data sources in this study are books that are relevant to the research, namely internet articles, previous research reports, books in the form of histories from Gunung Tidar Stories. Technique of Collecting Data.

\section{Results And Discussion}

The existence of the city of Magelang is wrapped by various legends. In ancient times, when the island of Java had just been created by the Creator in the form of a floating land in a vast ocean, the land moved to and fro. A god is then sent down from heaven to nail the land to stop moving. The head of the nail is used to nail the island of Java, eventually becoming a mountain which became known as Mount Tidar [11].

Another version of the story circulating in the surrounding community up to now, tells the heroism of Sheikh Subakir, an emissary from Iranian land who came to Java because of orders from Sultan Muhammad I (Sultan from Turkey, his place in Istanbul) to spread Islam in Java. Arriving at Mount Tidar, which is the kingdom of Jinn and supernatural kingdom ruled by Kiai Semar. Shaykh Subakir came to preach, not willing on the arrival of Shaykh Subakir, there was a fight between the king of Jinn, namely Kiai Semar and Shaykh Subakir. It turned out that Sheikh Subakir succeeded in conquering Kiai Semar, the king of jinn and his wife then fled to the South Sea to join Nyai Rara Kidul. Before running away, Raja Jinn swears that he will one day return to Mount Tidar, unless the people of this area are willing to become followers of Sheikh Subakir. Until now the people of Magelang live in peace with each other's beliefs [12].

During his life Sheikh Subakir spread the teachings of Islam to the end of his life and is buried on Mount Tidar until now as a place of pilgrimage before the month of Ramadan arrives [14]. In addition to the tomb of Shaykh Subakir, there is also the Spear of Shaykh Subakir's heirloom, the Kyai Sepanjang who defeated the jinn on Mount Tidar at his grave there. Unusual shape, 7 meters long with 1 meter wide. Both of these graves were discovered by Alm. KH Ahmad Abdul Haq Dalhar or better known as Mbah Mad, caretaker of the Darussalam Watucongol Muntilan Islamic boarding school. It is said that before it was discovered, this tomb was covered in a thicket of Mount Tidar. At the top of Mount Tidar there is a field in the middle of the field with a symbol with the symbol "Sa" in Javanese letters on three sides and according to the caretaker there means "Sopo is Wrong" or more or less means that whoever is guilty should admit his mistake. This monument is referred to as the Land of Java which makes the existence of the Land of Java remain calm and safe [13]. 


\subsection{Form of Gunung Tidar Folklore}

Legend is a people's prose that has characteristics similar to myth, which is considered to have actually happened. The legend describes events imagined in the past that are no longer known when they occur, they are supported by holy men who have supernatural powers or human beings who have a relationship with the world above, namely deity or heaven. Society believes that legends have occurred in the old times. Legends contain noble values that are beneficial to people's lives. Given the great significance of legend for the supporting community, it is necessary to conduct a study of legends that are still known and live in certain communities.

According to legend, Sheikh Subakir spread Islam, said the story circulating among the people, that Sheikh Subakir had a weapon named Kyai Sepanjang which was in the form of a spear that reached seven meters in length and for Java itself was placed on the top of Mount Tidar. So that what was done by Sheikh Subakir made the supernatural beings become, but finally Shaykh Subakir was able to conquer the supernatural nation. Since that incident, finally Shaykh Subakir was famous as the guardian of Allah who was able to conquer the unseen nation in the form of jinn and all other supernatural beings. Because of this incident too, the gentle nations who nested on Mount Tidar eventually 'fled' to the South Coast, which is the place of Nyai Roro Kidul. Based on the legend that used to be Mount Tidar was also a training ground (awareness) for prospective soldiers of the Sultanate of Mataram who were assigned to the Second Region (Magelang and Surrounding Areas).

The legend of the local community regarding Mount Tidar is still quite trusted until now and is one of the most legendary is "jalmo moro jalmo die" which means no one can confirm the fate of those who dare to climb Mount Tidar, it is said that if they do not die means they will faint fear. Besides that, Mount Tidar is one of the favorite places for those who study the science of kejawen around the tomb of Shaykh Subakir and eat Kyai Sepanjang. According to stories from the community, around the tomb is guarded by spirits who have supernatural energy that is extraordinary and tasked with guarding Mount Tidar, even it is said that almost every visitor will feel the magical energy. The Mystical Story of the Legend of Mount Tidar is indeed quite difficult to be accepted by human reason, but for the local community, the legend is still alive today [15].

\subsection{Function of Gunung Tidar Folklore}

The existence of folklore that lives and develops in the Magelang community, gives rise to certain functions within the supporting community. The functions contained in the Gunung Tidar Folklore are as follows:

1) As a projection system

The Magelang community believes in the existence of the Gunung Tidar Folklore with the supernatural forces possessed by Kyai Semar and Syekh Subakir. Shaykh Sheikh Subakir is considered to have supernatural powers so that many people who come with the aim of getting blessings so that his prayers are answered. Kyai Semar Petilasan visited by many visitors to worship because it is related to the science of kejawen.

2) As an instrument of ratification of institutions and cultural institutions

Gunung Tidar Folklore is able to shape thinking patterns and forms of cultural behavior that lives in its society. Society believes that folklore in its area is one form of cultural institutions that contains norms that are binding on the community, if these norms are violated then the community will receive the consequences. 
3) As an educational tool

The educational element contained in the Gunung Tidar Folklore is related to the spirituality between self and God. Humans must always remember the goodness of God in their lives by worshiping according to their respective religions and beliefs. The value of this education is implicit in the belief in the sacred place of Mount Tidar which is carried out with various ceremonies. Ability and determination to surrender to God Almighty through prayer and effort as hard as you can sure happiness and pleasure will come by itself. In addition, the community will continue to maintain good relations with each other and love the environment by preserving and preserving what already exists. Mount Tidar remains preserved and guarded even though it is in the middle of the city. There are three petilasan found in Mount Tidar, namely Sheikh Subakir, Kyai Semar and Kyai Sepanjang teaches children to love the environment more, especially in places considered sacred which are used for pilgrimage that must be kept clean.

4) as a tool of coercion and watchdog to keep society's norms in check

It is said that Shaykh Subakir was a great scholar who had sacrificed the land of Java from the negative influence of subtle creatures during the early spread of Islamic teachings in the archipelago. Human relations with the forces of nature can be shown in the form of rituals, a series of rituals is basically a real manifestation of the implementation of norms in their religion. Through trust in the figure of Sheikh Subakir, Kyai Semar, Kyai as long as they are used as a guide for them. While the cone ceremony every month Ruwah based on the Javanese calendar is used as a supervisor of the norms that apply in the community itself.

\subsection{Exemplary values that can be taken from Gunung Tidar Folklore}

The exemplary values that can be taken from the Gunung Tidar folklore are:

1) Moral Ethical Value

Through orders from Sultan Muhammad I, Sheikh Subakir and eight other scholars were sent to the land of Java to spread Islamic teachings because none of the previous emissaries had succeeded. The occult, the influence of Buddhist Buddhism is still very thick in the land of Java, animistic beliefs and worship of the spirits of the ancestors still have a strong influence on the land of Java. Sultan Muhammad I considered that Sheikh Subakir was able to become a pioneer of da'wah in Java despite the fact that spreading the teachings of Islam at that time was very difficult. Syekh Subakir accepts and is willing, without complaining, sent by Sultan Muhammad I to spread the teachings of Islam and fight all forms of resistance from spirits who have controlled the land of Java.

2) Religious Value

Sheikh Subakir was sent to the Javanese to quell the chaos that ensued after several emissaries of Sultan Muhammad I had not succeeded and were killed in Java. After defeating Kyai Semar, Shaykh Subakir did a great spread of Islamic teachings to change the mindset of the surrounding community that their previous beliefs could not bring them to heavenly happiness.

3) Culture value

The tomb of Sheikh Subakir, Tomb of Kiai Sepanjang, Tomb of Kyai Semar become one of the cultural attractions for visitors on Mount Tidar. There are so many motives for visitors to come to this place, there are those who send prayers to the spirits of ancestors, there are those who ask for welfare and fluency in various matters. The motives of these visitors are no longer a public secret, and are a habit that is routinely practiced by those who believe in them. 
4) Value of Struggle

Before the arrival of Sheikh Subakir, Mount Tidar was a haunted place, a forest that was inhabited by many spirits, djinns and dhedemites. Awesomeness of Mount Tidar causes local people to be afraid to enter the area. The old assumption "dead or modar" is still clearly happening that caused people to be reluctant to enter Mount Tidar. Then Syekh Subakir was sent to solve the problem, until he succeeded in his task. The struggle of Sheikh Subakir in crushing the creatures of the forest inhabitants of Mount Tidar was not in vain. The area of Mount Tidar brings peace and tranquility to the surrounding community since Shaykh Subakir lived and settled on Mount Tidar.

\section{Conlusion}

a. "Pakunya Tanah Jawa" is well known for Mount Tidar, which is located in the village of Magersari, Magelang Regency, Central Java Province. According to the kejawen myth, it is said that the deity descended to the Land of Java and planted a nail in the middle because the plains of the Land of Java moved due to ocean currents and formed Mount Tidar. Apart from these myths, geographically, it turns out that Mount Tidar is located in the middle of Java Island. From the historical side, there is a legend circulating in the narrative that tells of the heroism of Shaykh Subakir in conquering Kiai Semar, the powerful jinman of the businessman of Mount Tidar who at that time was a kingdom of spirits and jinns in the land of Java. Sheikh Subakir, a propagator of Islamic teachings from Turkey to preach on the land of Java, including the area around Mount Tidar.

The form of the Gunung Tidar Folklore is a legend because there is a human being who is a character in the story. The functions contained in the Gunung Tidar Folklore are the supernatural powers possessed by Kyai Semar and Syekh Subakir. Shaykh Sheikh Subakir is considered to have supernatural powers so that many people who come with the aim of getting blessings so that his prayers are answered, Gunung Tidar Folklore is able to form patterns of thinking and forms of cultural behavior that lives in his community. Humans must always remember the goodness of God in their lives by worshiping according to their respective religions and beliefs. The value of this education is implicit in the belief in the sacred place of Mount Tidar which is carried out with various ceremonies. Human relations with the forces of nature can be shown in the form of rituals, a series of rituals is basically a real manifestation of the implementation of norms in their religion. Through trust in the figure of Sheikh Subakir, Kyai Semar, Kyai as long as they become a guide for them.

b. The exemplary values that can be taken from the Gunung Tidar Folklore are that Sheikh Subakir accepts and is willing, without complaining, sent by Sultan Muhammad I to spread the teachings of Islam and fight all forms of resistance of spirits who have mastered the land of Java. Shaykh Subakir did the teachings of Islam to change the mindset of the surrounding community that their previous beliefs could not bring them to heavenly happiness. Tomb of Sheikh Subakir, Tomb of Kiai Sepanjang, Tomb of Kyai Semar become one of the cultural attractions for visitors on Mount Tidar. The struggle of Sheikh Subakir in combating the forest-dwelling creatures of Mount Tidar was not in vain. The area of Mount Tidar brings peace and tranquility to the surrounding community since Shaykh Subakir lived and settled on Mount Tidar 


\section{Sugestion}

This study revealed that the Gunung Tidar Folklore still gained public trust in Magelang that the legends passed down from generation to generation were still firmly planted in the minds of the people around Mount Tidar. become the cultural heritage of the Indonesian people. May the present and future generations continue to preserve Gunung Tidar Folklore and expand Mount Tidar tourism to supplement the Magelang regency's income.

\section{References}

[1] Alwi, Hasan, dkk. Tata Bahasa Baku Bahasa Indonesia (Edisi Ketiga. Jakarta: Balai Pustaka, 2003.

[2] Bascom, William. Four Functions of Foklore. Englewood Clifftd : NJ Prentice. hal 3-20, 1965.

[3] Danandjaja, James. Foklor Indonesia : Ilmu Gosip, Dongeng, dan lain-lain. Jakarta : Grafiti. hal 4, 1984.

[4] Suwardi Endaswara : Editor. Folklor Nusantara (Hakikat, Bentuk dan Fungsi).Yogyakarta : Ombak. hal 1, 2013.

[5] Adi, Generasi Pertama. Yogyakarta: Araska Publisher.hal. 142, 2007.

[6] Muallisin, Isnaini. Model Pengembangan Pariwisata Berbasis Masyarakat di Kota Yogyakarta. SIP ; Jurnal Penelitian Bappeda Kota Yogyakarta. Edisi 2, Desember 2007, ISSN 1978-0052, 2007.

[7] https://fahmianhar.com/gunung-tidar-magelang-legenda-dibalik-hutan-cemaral.

[8] https://kbbi.web.id/sinkretisasi penyerasian (penyesuaian, penyeimbangan, dan sebagainya) antara dua aliran (agama dan sebagainya).

[9] E. Sumaryono, Hermeneutika: Sebuah Metode Filsafat. Yogyakarta: Kanisius, 1999.

[10] D. Suryo Handono, Cerita Rakyat Jawa Tengah. Semarang: Balai Bahasa Provinsi Jawa Tengah, 2013.

[11] H. B. Mardikantoro, "Bahasa Jawa Sebagai Pengungkap Kearifan Lokal Masyarakat Samin Di Kabupaten Blora," Komunitas Int. J. Indones. Soc. Cult., vol. 5, no. 2, pp. 197-207, 2014.

[12] A. Triratnawati, "Konsep Dadi Wong Menurut Pandangan Wanita Jawa," Humaniora, vol. 17, no. 3, pp. 300-311, 2005.

[13] Sartini, “Abstract: Kata Kunci:," J. Filsafat, vol. 37, no. 2, pp. 111-120, 2004.

[14] D. Meirawan, "Trilogi Karakter Manusia dan Implikasinya Pada Pendidikan," J. Ilmu Pendidik., vol. 17, pp. 189-194, 2010.

[15] K. Saddhono and S. Supeni. "The role of dutch colonialism in the political life of Mataram dynasty: A case study of the manuscript of Babad Tanah Jawi." Asian Soc. Sci. vol. 10 no.15 pp. $1-7,2014$ 